\title{
Urgences
}

\section{Sans titre}

\section{Bernard Vargaftig}

Numéro 33, octobre 1991

Poésies parallèles : France - Québec

URI : https://id.erudit.org/iderudit/025661ar

DOI : https://doi.org/10.7202/025661ar

Aller au sommaire du numéro

Éditeur(s)

Urgences

ISSN

0226-9554 (imprimé)

1927-3924 (numérique)

Découvrir la revue

Citer ce document

Vargaftig, B. (1991). Sans titre. Urgences, (33). https://doi.org/10.7202/025661ar

Ce document est protégé par la loi sur le droit d'auteur. L'utilisation des services d'Érudit (y compris la reproduction) est assujettie à sa politique d'utilisation que vous pouvez consulter en ligne.

https://apropos.erudit.org/fr/usagers/politique-dutilisation/
Cet article est diffusé et préservé par Érudit.

Érudit est un consortium interuniversitaire sans but lucratif composé de l’Université de Montréal, l’Université Laval et l'Université du Québec à Montréal. Il a pour mission la promotion et la valorisation de la recherche. https://www.erudit.org/fr/ 


\section{Bernard Vargaftig}

\section{Renaud Longchamps}




\section{Sans titre}

\section{Bernard Vargaftig}

Le début de plus en plus immense

Un éclair le chemin en pente

L'écho n'a pas de désert le mur

Comme aurait échappé avec un peu d'ombre

Le réel le réel éparpille

La vitesse s'est dénouée

Le vent où ton nom vient de surgir

Où ce qui est tu érafle tout à coup

Le rideau déchiqueté la chambre

L'escalier le parfum la cour

L'abandon à côté de l'enfance

L'herbe et les paniers que la stupeur entraîne

Et crier ne se souvient de rien

Et quand la ressemblance allait

Du lilas si bruissant à l'espace

Dont l'aveuglement n'est jamais recouvert 
Le sable ne se tait pas

Le fracas les récifs l'odeur

D'un nom entre dispersion et ressemblance

Quand le paysage craque

Un mouvement de lumière

Rivage dévoré par l'aube

Un sentier à pic sous le premier instant

Le frôlement se dépêche

La proximité appelle

Les haies ramenaient le hasard

Un cri vient d'oublier c'est l'espace comme

Où l'exactitude aveugle

Les alisiers le bruant

L'escarpement toujours plus courbe

Grève et écho entraînaient dans le langage

La craie que rien ne rattrape 
32

Un instant a parcouru

La trace face à la stupeur

Effleurée éperdument après l'orage

Un côté de la broussaille

À peine un gué et les joncs

Le rivage le plus rapide

Quand distance et vent s'enfuyaient hors de l'ombre

Une pente se déchire

La profondeur me saisit

Et le commencement tremble

Où voir voir n'est jamais le même silence

Comme s'envolait la crique

Que la lumière répète

L’oubli dans la vivacité

Un loriot tout à coup un frémissement

Dont aucun mot ne s'éloigne 
Ton regard renversé sous l'enfance

Était-ce à pic tu me détaches

Le précipice va arriver

L'étendue avant l'éclat tellement nu

Les roches quand aucun mot n'est autre

Trop de craie rupture après rupture

Vérité mouettes fuite brève

Distance et chaque fois le sentier vacille

Quelle déchirure se disperse

Presque une trace sans trace un

Feuillage insaisissable précède

Et emmène la peur à travers l'été

L'esquive avec l'oubli où la plage

Glissait près du consentement

Jamais muet d'être effacé comme

L'obscurité et le jasmin ont bougé 
34

Nommer n'a pas d'horizon

Une histoire au milieu d'un cri

Quand l'aveu devient connaissance et odeur

Un éboulis chaque fois

Où dans la stupéfaction

Étendue après étendue

L'écho interminable entourait les guêpes

Quel gouffre m'éblouissait

Les hortensias une rue

La mémoire tout se déplace

Mur nappe et vitre une phrase abandonnée

Aucune ombre la distance

Si le tremblement qui s'ouvre

Comme effacé par son image

Et que la nudité ne dira jamais

Avait grondé sous l'éclair 